MAŁGORZATA PAPLIŃSKA

Wydział Nauk Pedagogicznych

Akademia Pedagogiki Specjalnej

Warszawa
Forum Pedagogiczne 2016/1

Wpłynęło: 11.01.2016 Zatwierdzono do druku: 13.03.2016

\title{
NIEWIDOMY ODBIORCA SZTUKI - SPOŁECZNE, EDUKACYJNO-REHABILITACYJNE ZNACZENIE AUDIODESKRYPCJI PRZEDSTAWIEŃ TEATRALNYCH DLA OSÓB Z NIEPEŁNOSPRAWNOŚCIĄ WZROKU
}

Streszczenie: Udostępnianie sztuki, zwłaszcza przedstawień teatralnych i filmów, osobom niewidomym ma ogromne znaczenie w ich aktywizacji społecznej, jak również spełnia rolę edukacyjno-rehabilitacyjną. Udział osób niewidomych w warsztatach teatralnych sprawia, że mogą być w pełni uczestnikami i odbiorcami sztuki. Audiodeskrypcja spektakli sprzyja zrozumieniu niedostępnych dla dzieci niewidomych pojęć.

Słowa kluczowe: sztuka dostępna dla osób niewidomych, audiodeskrypcja (AD), rozumienie pojęć, warsztaty teatralne dla osób niewidomych

\section{Wstęp}

Przyjmując w uproszczeniu, że udany kontakt ze sztuką wymaga co najmniej dwóch niezwykle ważnych elementów - dzieła i odbiorcy, należałoby oczekiwać, że dzieło będzie dostępne dla percepcji odbiorcy, by jako widz, dzięki umiejętnościom poznawczym i wrażliwości estetycznej, miał szansę wejść w interakcję z dziełem. Nie bez znaczenia są jego wcześniejsze doświadczenia i kontakt ze sztuką, uwarunkowania historyczne, kulturowe oraz indywidualne, bo z nich wypływają sądy estetyczne i stan oraz charakterystyka postrzegania świata w ogóle (De Coster, Loots 2004). Sztuka nie może bytować sama dla siebie, musi istnieć twórca wraz z własną, indywidualną ekspresją oraz odbiorca.

Małgorzata Makówka zwraca uwagę, że najczęściej uczestnictwo w kulturze polega na udziale w kulturze artystycznej, a więc dziedzinie kultury symbolicznej, która „wiąże się z tworzeniem i recepcją wartości estetycznych. Chodzi tu zarówno o kulturę elitarną, wymagającą od odbiorcy znacznej wrażliwości na wartości estetyczne, dużej koncentracji, wysiłku umysłowego, emocjonalnego napięcia oraz 
wysokiego poziomu kompetencji kulturowych, jak i o kulturę popularną, łatwą w odbiorze dzięki prostocie i przystępności treści” (Makówka 2007, s. 5-6).

Sztuka niesie ze sobą wartości estetyczne, dzięki którym dostarcza swoistych przeżyć powstających w czasie kontaktów człowieka $\mathrm{z}$ formami artystycznej twórczości. Dynamiczne napięcie powstałe w wyniku przeżywania sztuki, np. uczucie radości, smutku, nostalgii, może wpływać na ogólną aktywność człowieka i być wykorzystywane w kształtowaniu postaw społecznych, moralnych, jak również w pobudzaniu do działania. Pod wpływem dynamiki uczuć człowiek wykazuje się większą aktywnością, dużą samodzielnością i wyobraźnią (Kuczyńska-Kwapisz, Paplińska 2006).

Irena Wojnar zaznacza, że sztuka, towarzysząc człowiekowi przez całe życie, staje się źródłem nowych doznań oraz przyczynia się do odkrywania wiedzy o sobie oraz otaczającej rzeczywistości i świecie w ogóle. Jak wskazuje autorka: „sztuka zarysowuje się jako zasługujący na uwagę «instrument» kształcenia człowieka, nie tylko w zakresie jego kultury estetycznej, lecz i we wszystkich innych zakresach przeżyć i działań” (Wojnar 1970, s. 10).

\section{Uczestnictwo w kulturze i jej dostępność}

Aktywność kulturalna ujmowana jest jako samodzielne bądź inspirowane kontaktowanie się pojedynczych osób i grup ludzkich z określonymi wartościami i tworzywem kultury oraz sztuki. Zdaniem Krzysztofa Czykiera (2013, s. 63) aktywność kulturalna „wraz z takimi kategoriami, jak uczestnictwo w kulturze, uczestnictwo kulturalne, życie kulturalne, obecne są w opisach i wyjaśnianiu zjawisk związanych z partycypacją człowieka w danej kulturze [...]. Nie może istnieć uczestnictwo w kulturze bez jakiegokolwiek przejawu aktywności. W kulturze nie można uczestniczyć biernie, ponieważ każde uczestnictwo jest w jakimś stopniu aktywne”. Kultura jest sferą otaczającą człowieka ze wszystkich stron, a więc człowiek niejako jest w niej zanurzony (Golka 2007).

Literatura przedmiotu wskazuje wiele klasyfikacji wymiarów uczestnictwa w kulturze. Jedną z nich przedstawia Hanna Żuraw (1995), koncentrując się na recepcji, która jest złożonym procesem zmian zachodzących w jednostce pod wpływem uczestnictwa w kulturze, oraz ekspresji, wyrażonej aktywnością związaną ze stwarzaniem szans wyrażania niepokoju i przekształcania go w napięcie efektywne społecznie. Dzięki recepcji aktywność człowieka polegająca na słuchaniu, oglądaniu filmów lub obrazów, udziale w koncertach, czytaniu literatury prowadzi do wzbogacenia doświadczeń poznawczych, uczuciowych, jak również sprzyja pobudzaniu wrażliwości i budowaniu zainteresowania, a także postaw. Ekspresja jako działanie przyjmuje różne formy i poziomy: od pracy i działalności społecznej po hobby czy twórczość jednostki (Grzebinoga 2011). Anna Grzebinoga akcentuje fakt, że człowiek „przez ekspresję w kulturze zaspokaja potrzebę bezpieczeństwa, 
komunikacji międzyludzkiej, doznawania wrażeń i obcowania ze światem; uczy się doświadczać wartości w procesie działania" (tamże, s. 152).

Według Janusza Gajdy (2012) kultura pełni wiele funkcji. Nie tylko poszerza wiedzę o świecie i zwielokrotnia doświadczenia osobiste, ale także ułatwia zrozumienie siebie i drugiego człowieka. Kultura pomaga w kształtowaniu i stabilizowaniu systemu wartości, tworzy płaszczyzny porozumienia z innymi ludźmi oraz sprzyja budowaniu więzi między jednostkami a grupami. Partycypacja w kulturze pełni wielorakie funkcje społeczne. Małgorzata Makówka (2007) zwraca uwagę między innymi na jej znaczenie w przywracaniu człowiekowi zachwianej równowagi psychicznej, wzbogacaniu wiedzy i doskonaleniu sprawności umysłowych oraz dyspozycji twórczych. Podkreśla również takie funkcje jak: budzenie i rozwijanie zainteresowań, potrzeb ludzkich, jak również kształtowanie nie tylko wrażliwości estetycznej i emocjonalnej, ale również postaw moralnych oraz systemu wartości człowieka. Autorka akcentuje również fakt, że udział w kulturze pozwala na tworzenie i wzmacnianie więzi społecznych, doskonalenie stosunków międzyludzkich oraz rozszerzanie możliwości adaptacyjnych człowieka, a także zwiększanie jego przestrzennej, zawodowej i społecznej aktywności oraz ruchliwości (tamże).

Podobnie jak Janusz Gajda wielu autorów podkreśla, że w odniesieniu do osób z niepełnosprawnością kultura ma charakter przede wszystkim rewalidacyjny (Baraniewicz, Gunia 2006; Grzebinoga 2011; Makówka 2007; Pichalski 1995; Podgórska-Jachnik 2011). Danuta Baraniewicz i Grażyna Gunia (2006, s. 149-150) przytaczają za Ryszardem Pichalskim (1995) funkcje rewalidacyjne, jakie pełni aktywność kulturalna osób z niepełnosprawnością. Są wśród nich:

- funkcja integracyjna, sprzyjająca zacieśnianiu kontaktów pomiędzy członkami poszczególnych grup społecznych, na przykład osobami należącymi do jednego zespołu artystycznego, muzycznego czy teatralnego;

- funkcja kompensacyjna, polegająca na wyrównywaniu ograniczeń lub braków, które są następstwem niepełnosprawności, jak również wynikają z barier społecznych;

- funkcja terapeutyczna, mająca formę aktywnej działalności twórczej lub przeżywania dzieł sztuki;

- funkcja rekreacyjno-rozrywkowa, pozwalająca na odpoczynek i odreagowanie stresu poprzez udział w formach życia kulturalnego;

- funkcja profilaktyczna, zapobiegająca np. izolacji społecznej, depresji i innym wtórnym skutkom i zaburzeniom wynikającym z niepełnosprawności.

Ciekawe dane dotyczące dostępności kultury w Polsce, rozumianej jako łatwość, z jaką ludzie mogą uczestniczyć w życiu kulturalnym, przedstawił Tomasz Kukołowicz (2015). Dzięki geograficznemu wskaźnikowi dostępności kultury, opracowanemu przez Zespół ds. Statystyki Kultury działający w Narodowym Centrum Kultury, można zaobserwować, jak miejsce zamieszkania wpływa na łatwość uczestniczenia w życiu kulturalnym. Wskaźnik ten oparty jest m.in. na liczbie wydarzeń kulturalnych, zarówno bezwzględnej, jak i w przeliczeniu na jednego 
mieszkańca. Uwzględnia on na przykład dostęp do dziedzictwa oraz instytucji kultury, takich jak: teatr, galeria, muzeum, filharmonia, jak również kulturalnych wydarzeń jednorazowych, a także, co ciekawe, dostęp do internetu. Przytaczane przez autora dane wskazują, że geograficzny wskaźnik dostępności kultury w 2014 r. miał najwyższą wartość w Krakowie (78 pkt), Warszawie (75,9 pkt) i Sopocie (74 pkt), a najniższą w powiatach otaczających Radom (białobrzeskim - 19,4 pkt, lipskim - 21 pkt, radomskim - 25,1 pkt) (tamże). W Krakowie był najłatwiejszy w Polsce dostęp do dziedzictwa i specjalistycznych instytucji kultury (teatrów, filharmonii, galerii) oraz jednorazowych wydarzeń kulturalnych. Autor zwraca uwagę na pozytywny wpływ domów kultury, bibliotek i internetu na dostęp do kultury w ogóle i wskazuje na zaskakującą relację pomiędzy instytucjami kultury pierwszego kontaktu (domy kultury, biblioteki, kina) a wyspecjalizowanymi instytucjami kultury (teatry, filharmonie, galerie). Okazuje się bowiem, że tam gdzie jest dużo teatrów i galerii, mniej jest domów kultury, bibliotek i kin.

Brak jest niestety danych dotyczących dostępności kultury dla osób niewidomych i słabowidzących oraz aktywności tej grupy w życiu kulturalnym, zarówno jako twórców, jak i odbiorców. Wyniki badań Katarzyny Pietruszyńskiej (2015) nad audiodeskrypcją (AD) jako formą rehabilitacji, prowadzonych w ramach seminarium dyplomowego, wskazują, że dostępność wydarzeń audiodeskrybowanych i częstotliwość korzystania z nich przez osoby z dysfunkcją wzroku są bardzo niskie. Wśród 30 badanych osób z niepełnosprawnością wzroku (głównie niewidomych i ociemniałych oraz pięciu słabowidzących) w wieku od 20 do 60 lat, którzy korzystają z wydarzeń audiodeskrybowanych realizowanych przez Fundację Kultury Bez Barier, zaledwie dwoje uczestniczyło w swoim życiu w ponad 20 dostosowanych do ich możliwości wydarzeniach. Zdecydowana większość (60\%) korzystała z nie więcej niż 10 wydarzeń audiodeskrybowanych. Jednocześnie w opinii 80\% badanych wydarzeń audiodeskrybowanych jest bardzo mało (40\%) lub mało (40\%). Wśród badanych większość (48\%) korzystała z AD seansów filmowych, $26 \% \mathrm{z}$ AD spektakli teatralnych, $11 \% \mathrm{z}$ AD wystaw muzealnych i galerii, a $4 \% \mathrm{z} \mathrm{AD}$ imprez sportowych (Pietruszyńska 2015).

Karin De Coster i Gerrit Loots (2004) stawiają pytanie: dlaczego w ogóle warto osobom niewidomym pokazywać sztukę, jeśli w większości są to dzieła wizualne? Czy ta konfrontacja jest potrzebna i czy ma sens? Autorki podkreślają, że nietrudno znaleźć odpowiedź na te pytania, ponieważ osoby z niepełnosprawnością wzroku bardzo często wykorzystują pojęcia wizualne. Są wśród nich zarówno ociemniali, którzy kiedyś widzieli i pamiętają obrazy wzrokowe, jak i całkowicie niewidomi, dla których głównymi kanałami zdobywania informacji o świecie są dotyk i słuch, ale którzy doskonale zdają sobie sprawę, jak ważne we współczesnym świecie jest widzenie (tu rozumiane jako dostęp do prezentowanych w formie obrazu informacji) (tamże). Odbiorcami sztuki, o których nie należy zapominać, są osoby w różnym stopniu słabowidzące, także te, które mimo niewielkich możliwości wzrokowych wciąż korzystają z tego zmysłu, często jako głównego kanału 
zdobywania informacji. Niezależnie od możliwości wzrokowych lub ich braku ludzie są ciekawi sztuki, ponieważ jest to istotny aspekt ich życia i źródło informacji o świecie, społeczeństwie, kulturze, a także o zachodzących w nich zmianach.

\section{Audiodeskrypcja przedstawień teatralnych}

Ustawa $z$ dnia 25 marca 2011 r. o zmianie ustawy o radiofonii $i$ telewizji definiuje audiodeskrypcję (AD) jako werbalny, dźwiękowy opis obrazu i treści wizualnych zawartych w audycji audiowizualnej, przeznaczony dla osób niepełnosprawnych z powodu dysfunkcji narządu wzroku, umieszczony w audycji lub rozpowszechniany równocześnie $\mathrm{z}$ audycją. Według Izabeli Künstler i Urszuli Butkiewicz audiodeskrypcja to opis umożliwiający osobom niewidomym odbiór filmów, przedstawień teatralnych, sztuk plastycznych oraz wszelkich innych przekazów wizualnych (Künstler, Butkiewicz b.d.).

Agnieszka Szarkowska i Izabela Künstler (b.d., s. 64) zwracają szczególną uwagę na praktyczny wymiar audiodeskrypcji. W tym kontekście AD definiowana jest przez nie jako „technika opisywania filmów osobom niewidomym i słabowidzącym. To: «co», «kto», «kiedy», «jak» $\mathrm{i}$ «gdzie» danego filmu, dołączone w postaci dodatkowej ścieżki dźwiękowej z odczytanym przez lektora opisem: wydarzeń, wyglądu bohaterów, miejsca akcji itp. Tekst audiodeskrypcji dyskretnie wplata się pomiędzy dialogi i inne dźwięki, tworząc z nimi jednorodną całość”.

Zdaniem Agnieszki Chmiel i Iwony Mazur (2014) najpopularniejszym źródłem $\mathrm{AD}$ jest dziś telewizja. Wynika to zarówno z różnorodności audycji (programy rozrywkowe, filmy, transmisje sportowe), jak też preferencji osób starszych, które są głównymi odbiorcami AD w domu. Zatem, jak wskazują autorki, priorytetem w popularyzacji audiodeskrypcji powinna być zwiększona dostępność AD w telewizji, jak również wykorzystanie jej do udostępniania osobom z niepełnosprawnością wzroku innych mediów i kanałów komunikacji społecznej, np. AD wystawy muzealnej, spektaklu teatralnego i muzycznego oraz baletu, koncertu i innych wydarzeń kulturalnych lub sportowych (Paplińska 2015). Tymczasem mimo zwiększonego zapotrzebowania na programy audiodeskrybowane Ustawa $z$ dnia 12 października 2012 r. o zmianie ustawy o radiofonii i telewizji oraz Rozporzadzenie Krajowej Rady Radiofonii i Telewizji z dnia 28 maja 2013 r. zmniejszają udział audycji z udogodnieniami odbioru dla osób z niepełnosprawnością wzroku i słuchu z 10\% kwartalnego czasu nadawania programu do co najmniej 1\% kwartalnego czasu nadawania programu, z wyłączeniem reklam i telesprzedaży, dla programów o zasięgu ludnościowym nieprzekraczającym 200 ooo mieszkańców i do co najmniej 5\% kwartalnego czasu nadawania programu dla programów o zasięgu nieprzekraczającym 500 ooo mieszkańców.

Warto zwrócić uwagę na rolę i charakter AD, która ma poruszać odbiorców niewidomych w takim samym stopniu jak widzów korzystających ze wzroku. $\mathrm{Z}$ tego względu AD to nie tylko opis scenografii i kostiumów, ale także informacja 
o emocjach, mowie ciała bohaterów, nieograniczająca się tylko do opisu gestów lub mimiki (Künstler 2014).

Szczególnym rodzajem AD jest ta realizowana podczas przedstawień teatralnych. W Polsce pojawiła się ona po raz pierwszy w teatrze w 2007 roku. Z inicjatywy Fundacji Audiodeskrypcja w Białostockim Teatrze Lalek wystawiono bajkę Jest królik na księżycu. Największy dorobek w dziedzinie AD teatralnej ma jednak Fundacja Dzieciom „Zdążyć z Pomocą”, która w ramach projektu „Poza ciszą i ciemnością" w teatrach Warszawy, Krakowa i Poznania w latach 2009-2012 przygotowała 26 premier (Szarkowska, Künstler b.d.).

Formalnie AD teatralna nie różni się od filmowej, bo także opisuje sztukę audiowizualną i jest ograniczona czasem, a tekst czytany przez lektora musi się zmieścić między dialogami. Autorki wskazują jednak na różnice, które wynikają „ze specyfiki przedstawienia teatralnego jako wydarzenia jednorazowego, dziejącego się na żywo i za każdym razem zawierającego element niespodzianki" (tamże, s. 94). Aktorzy mogą robić pauzy w innych miejscach niż w czasie zarejestrowanego przedstawienia, na podstawie którego pisany jest tekst. Często improwizują, wykonują różne gesty. Zdarza się także zmiana techniczna w postaci np. wymiany rekwizytu czy pominięcia całych scen. Każde przedstawienie jest niepowtarzalne i różni się od innych czasem trwania, wynikającym z różnego tempa wypowiadania tekstu przez aktorów (Holland 2009). Z uwagi na tę specyfikę AD musi być odczytywana na żywo, a audiodeskryptor powinien być gotowy na modyfikacje wcześniej napisanego skryptu, zgodnie z tym, co się dzieje na scenie. Widzowie z niepełnosprawnością wzroku słuchają opisu przez słuchawki (najlepiej jednej, aby drugim uchem łowić dźwięki ze sceny i otoczenia), a wykorzystywana technologia to przekaz sygnału przez fale radiowe lub podczerwień (analogicznie do tłumaczenia symultanicznego) (Chmiel, Mazur 2014).

W AD przedstawień teatralnych pojawia się trudność związana z opisem przestrzeni scenicznej i scenografii. Jeśli inscenizacja umieszczona jest na tradycyjnej scenie pudełkowej, w opisie mogą wystarczyć określenia: na prawo, na lewo, w głębi. Jednak w sytuacji, gdy kształt sceny jest nieco inny, a aktorzy pojawiają się wśród widzów, wkraczając także z tyłu, z góry, z dołu, trudność w opisywaniu jest większa, bo wymagana jest precyzyjności przekazu, aby informacja dla niewidomych odbiorców sztuki była zrozumiała (Szarkowska, Künstler b.d.).

Na szczególną uwagę zasługuje audiodeskrypcja dla dzieci, która ma nieco inny charakter ze względu na język, formę przekazu i zaangażowanie lektora. Należy mieć też świadomość, że AD to kolejne, obok samej ścieżki dźwiękowej, źródło informacji, które dzieci muszą zrozumieć i przyswoić (Orero 2011). AD dla tej grupy odbiorców musi spełniać trzy kryteria: być zrozumiała, ciekawa i przekazana w atrakcyjny sposób. Pierwsze kryterium oznacza uwzględnienie przez audiodeskryptora możliwości poznawczych niewidomych małych dzieci. W takim AD należy pamiętać, że dzieci niewidome od urodzenia często mają opóźniony rozwój językowy ze względu na ograniczenia poznawcze wynikające z dysfunkcji 
wzroku. Oznacza to, że język i tempo AD należy dostosować do wieku i specyfiki odbiorców (Chmiel, Mazur 2014; Orero 2011; Paplińska 2015). Warto zatem zwrócić uwagę na szczególny, bo edukacyjny, aspekt AD dla dzieci z niepełnosprawnością wzroku, ponieważ dzięki niej mogą nauczyć się pojęć oczywistych dla ich widzących rówieśników. Z tego względu pewne pojęcia i zjawiska oraz sytuacje, zwłaszcza trudno dostępne $\mathrm{z}$ powodu braku lub znacznego ograniczenia wzroku, powinny być opatrzone dodatkowo komentarzem, aby stały się zrozumiałe i czytelne.

Wyboru lektora AD dla dzieci powinno się dokonywać ze szczególnym namysłem, ponieważ jego zaangażowanie pozwoli utrzymać uwagę dziecka, wzbudzić w nim emocje, jakie niesie ze sobą film, spektakl czy bajka. Udział w wydarzeniu $\mathrm{z} \mathrm{AD}$ powinien być dla dziecka przede wszystkim zabawą, nie może więc mieć ono znamion przeładowanego informacjami programu czy przedstawienia (Paplińska 2015).

\section{Społeczne, edukacyjno-rehabilitacyjne znaczenie udostępniania przedstawień teatralnych osobom $\mathrm{z}$ niepełnosprawnością wzroku}

Dorota Podgórska-Jachnik definiuje scenę jako „miejsce pokazywania kogoś lub czegoś - ludzi, zdarzeń, emocji. To umowne pole skupiania uwagi widza, który właśnie tak się nazywa, gdyż przychodzi oglądać spektakl, deklaruje swoją uwagę, otwarcie poznawcze, gotowość komunikacji i zatrzymania osobistego czasu pozateatralnego na czas trwania przedstawienia, aby tę deklarację wcielić w życie" (Podgórska-Jachnik 2011, s. 94).

W ramach seminarium dyplomowego Dorota Strachel (2015) przeprowadziła badania, których celem była ocena dostępności sztuki dla osób z dysfunkcją wzroku lub słuchu w Teatrze Rozmaitości w Warszawie. Przebadała ona m.in. 11 osób niewidomych i trzech pracowników teatru zajmujących się udostępnianiem przedstawień teatralnych osobom $z$ niepełnosprawnością sensoryczną. Teatr Rozmaitości ma w swej ofercie szeroki program edukacyjny, który obejmuje warsztaty skierowane do różnych grup - dzieci, młodzieży, seniorów, a także osób z niepełnosprawnością. Twórcy teatru mówiąc o jego misji, obok pobudzania refleksji i poszerzania przestrzeni dialogu społecznego, wskazują także na istotną rolę likwidowania barier w dostępie do sztuki różnych grup społecznych. Od 2013 roku w teatrze jest realizowany program „TR bez barier”. Jest to oferta odpowiadająca na potrzeby osób z niepełnosprawnością sensoryczną, obejmująca spektakle z AD na żywo i napisami oraz warsztaty, które mają na celu przygotowanie widzów niewidomych i słabowidzących do odbioru wystawianych sztuk (Strachel 2015).

Głównym celem warsztatów jest umożliwienie osobom $\mathrm{z}$ niepełnosprawnością dotknięcia tematu i formy sztuki, aby była ona w pełni czytelna i zrozumiała. W związku z tym obejmują one najczęściej zapoznanie uczestników z tzw. wstępną audiodeskrypcją, zawierającą wszystkie informacje, na które nie ma miejsca podczas czytania opisów w trakcie spektaklu. Wstępna AD obejmuje 
m.in. przedstawienie postaci, ich opis, charakterystykę miejsca wydarzeń (w tym np. tła społeczno-historycznego), scenografii itp. Kolejnym etapem jest poznanie kostiumów i rekwizytów. Prawie wszyscy uczestnicy warsztatów uznali możliwość dokładnego poznania sceny za ważny i potrzebny etap udostępniania sztuki. Wejście osób niewidomych na scenę, dotknięcie scenografii i wszystkich istotnych elementów (np. kluczowych rekwizytów) wykorzystywanych w przedstawieniu pozwala im zbudować wyobrażenie spektaklu, a przede wszystkim zrozumieć jego treść i przekaz. Oto wypowiedzi uczestników warsztatów, podkreślające znaczenie dosłownego dotknięcia sztuki: „fantastyczna jest możliwość obejrzenia rekwizytów, scenografii; w dodatku sam fakt wejścia na scenę, po której poruszają się aktorzy, jest bardzo ekscytujący”, „gdy wiem, jak wygląda scenografia i jak są ubrani aktorzy, to podczas spektaklu mogę to sobie wyobrazić i w połączeniu z dialogami w końcu składa się to w całość” (Strachel 2015, s. 44).

W Teatrze Rozmaitości przybliża się sztukę także poprzez proponowanie udziału w działaniach performatywnych. Ich uczestnicy mogą spróbować doświadczyć na sobie działań, które potem pomogą lepiej zrozumieć spektakl, zwłaszcza trudniejszą w odbiorze sztukę awangardową. Ten element warsztatów, prowadzony przez pedagogów teatru, polega najczęściej na improwizowanym czytaniu tekstów, poprzedzonym ćwiczeniami fizycznymi, mentalnymi i integracyjnymi. Istotne jest, aby działania mające na celu przybliżenie trudnych do zrozumienia kwestii sztuki pozwalały widzowi w trakcie spektaklu odnieść się do emocji, jakich doświadczył na warsztatach (Strachel 2015).

Dla wielu uczestników warsztatów jest to formą oswojenia się z teatrem, a dla osób ociemniałych często bywa powrotem do dawnego życia (sprzed utraty wzroku), gdy byli aktywnymi uczestnikami kultury. W uzasadnieniach dotyczących przydatności warsztatów znalazły się następujące wypowiedzi osób niewidomych:

- „właściwie wszystkie elementy warsztatów były dla mnie bardzo istotne w przygotowaniu do odbioru sztuki, ponieważ bez tego wątpię, by spektakl był dla mnie zrozumiały";

- „dzięki improwizacjom i wcielaniu się w role bardziej rozumiem sztukę”;

- „przybliżenie tematyki spektaklu i przedstawienie bohaterów sztuki jest dobrym przygotowaniem do spektaklu”;

- „poznanie wizji reżysera i autora oraz charakterystyki postaci pozwala mi lepiej zrozumieć sztukę";

- „ćwiczenia z wybranymi dialogami lub przesłaniami sztuki umożliwiają wczucie się w klimat czy dramaturgię spektaklu” (Strachel 2015, s. 44).

Wszyscy respondenci określili atmosferę panującą na warsztatach jako swobodną i sprzyjającą otwartej komunikacji oraz współpracy. Najczęściej podkreślano otwartość prowadzących:

- „nie ma sztywnych ram, jeżeli mam jakiś pomysł, to wiem, że mogę się nim podzielić i on na pewno spotka się z akceptacją innych osób”; 
- „nie ma złych pomysłów, każde działanie jest przyjmowane przez innych uczestników z otwartością";

- „W improwizacjach graliśmy to, na co mieliśmy ochotę, bez zbędnego scenariusza - to dało mi dużą swobodę”, „improwizacja pomaga mi uwolnić emocje";

- „taki rodzaj wspólnej kreatywnej zabawy sprzyja otwieraniu się na innych” (Strachel 2015, s. 44).

Udostępnienie przedstawień teatralnych osobom niewidomym i słabowidzącym ma ogromne znaczenie, które należy rozpatrywać wieloaspektowo - z punktu widzenia wyrównywania szans i przeciwdziałania marginalizacji, jak również w kontekście edukacyjnym i autorewalidacyjnym. Warto zaznaczyć, że szczególnie ta grupa osób, ze względu na swoje ograniczenia w bezpiecznym poruszaniu się, wywołane lękiem lub brakiem wystarczających umiejętności związanych z orientacją przestrzenną i samodzielnym poruszaniem się z białą laską, jest narażona na izolację społeczną, a tym samym pozostanie na marginesie uczestnictwa w kulturze. Dyskryminacja osób niewidomych i słabowidzących wynika przede wszystkim z faktu, że liczba dostępnych dla nich miejsc, instytucji kultury i wydarzeń artystycznych jest wciąż niewystarczająca, co w zdecydowany sposób wpływa na ich obserwowaną niską aktywność kulturalną. Należy wyraźnie zaznaczyć, że każde przedsięwzięcie kulturalne skierowane do osób z niepełnosprawnością wzroku lub choćby dostosowane do ich możliwości odbioru jest ważnym czynnikiem, niejednokrotnie w ogóle motywującym do wyjścia $z$ domu.

Z przytaczanych już badań Pietruszyńskiej (2015) wynika, że 97\% osób z niepełnosprawnością wzroku deklaruje, iż czuje się zintegrowane ze społeczeństwem w czasie uczestnictwa $\mathrm{w}$ audiodeskrybowanych wydarzeniach kulturalnych. Uczestnicy warsztatów w Teatrze Rozmaitości bardzo mocno podkreślają ten aspekt w swych wypowiedziach:

- „na pewno nareszcie mogę rozmawiać z osobami pełnosprawnymi na temat oglądanych spektakli i dzielić się wrażeniami”, „każde tego typu działania powodują łamanie barier nie tylko w dostępie do kultury, ale też w kontaktach międzyludzkich";

- „mogę zabrać głos na temat problemów poruszanych w oglądanej sztuce” (Strachel 2015, s. 46).

Nie do przecenienia jest wartość edukacyjna $A D$, czyli umożliwienie osobom z niepełnosprawnością wzroku samodzielnego oraz pełniejszego odbioru treści, które bez percepcji wzrokowej nie byłyby możliwe nie tylko do uchwycenia, ale i zrozumienia. Konkretny, dobrze zrobiony opis obrazu czy sceny daje osobom niewidomym i słabowidzącym możliwość odbierania sztuki. Widoczne to jest w ich wypowiedziach: „audiodeskrypcja pomaga mi zobaczyć kolory, ruch, zmiany scenografii, gesty i mimikę aktorów - krótko mówiąc, wszystko to, co dzieje się na scenie poza dialogami, więc mogę doświadczać sztuki w pełni”; „kiedy straciłem wzrok, długo unikałem chodzenia do teatru, bo zwyczajnie nie widziałem, co działo 
się na scenie, teraz dzięki audiodeskrypcji powróciłem do oglądania spektakli” (Strachel 2015, s. 44-45).

Dobrze przygotowana i zrealizowana AD przyczynia się do rozwoju słownika i zrozumienia pojęć przestrzennych, pojęć surogatowych. Warto zaznaczyć, że percepcja osoby niewidomej jest częściowa i zmuszona jest ona do pozostawania na poziome reprezentacji pełniących funkcję kompensacyjną. Reprezentacje, nazywane wyobrażeniami surogatowymi (zastępczymi), są pewnymi substytutami psychicznymi tych treści poglądowych, które dla ludzi niewidomych są zupełnie lub częściowo niedostępne, a odgrywają ważną rolę w kształtowaniu wyobrażeń i pojęć. Można wyróżnić dwa rodzaje wyobrażeń zastępczych. Pierwszy dotyczy stosunków przestrzennych, których osoba niewidoma nie może w sposób adekwatny ująć albo robi to $\mathrm{z}$ wielkim trudem (Paplińska 2008). Osoby niewidome posługują się pojęciami odwołującymi się do wizualnych cech przedmiotów i zjawisk, a dzięki umiejętności tworzenia wyobrażeń surogatowych są w stanie rozumieć oraz wykorzystywać je w sposób prawidłowy i adekwatny. Audiodeskrypcja może nie tylko pomóc osobom $\mathrm{z}$ niepełnosprawnością wzroku w prawidłowym tworzeniu wyobrażeń surogatowych, ale również przez dodatkowy komentarz ułatwić zrozumienie trudno dostępnych dla nich pojęć.

Kompensacyjna i rehabilitacyjna rola teatru w życiu osób niepełnosprawnych została zaakcentowana przez Dorotę Podgórską-Jachnik (2011), która przytaczając wyniki badań prowadzonych nad teatrem głuchych, zwróciła uwagę na sformułowane przez osoby badane cele, jakim według nich służy teatr. A więc ma on cel kompensacyjny, bo stwarza umowną rzeczywistość dramatyczną, z której można bezpiecznie wyjść. Ponadto jest miejscem bez ograniczeń, w którym można spełniać swoje marzenia. Teatr służy także w ich opinii celom rehabilitacyjno-terapeutycznym, ponieważ stwarza możliwość wyzwolenia ukrytych emocji zarówno widza, jak i aktora, oraz uwolnienia od lęków i likwidacji emocjonalnych napięć. Jednym z celów wskazanych przez badanych było także wspieranie rozwoju osobistego - osobotwórczy potencjał teatru polega na samorealizacji, przełamywaniu swoich ograniczeń, budowaniu poczucia własnej wartości. Tę kompensacyjno-rehabilitacyjną rolę teatru należy odnieść do całej kultury, w której uczestniczą osoby z niepełnosprawnością wzroku, zwłaszcza do działań zbliżonych do tych realizowanych w projekcie „TR bez barier”. Kompensacja sensoryczna i psychologiczna pozwala osobom niewidomym i słabowidzącym dotknąć sztuki, w pełni ją przeżyć. Uczestnictwo w warsztatach daje możliwość poszerzenia osobistych doświadczeń, wypróbowania siebie w bezpieczny sposób oraz, co ważne, przełamania wewnętrznych barier i ograniczeń. Jak pisze Dorota Podgórska-Jachnik: „możliwości, jakie stwarza teatr, przystają bowiem w niezwykły sposób do specjalnych potrzeb wynikających z niepełnosprawności” (2011, s. 100). 


\section{Podsumowanie}

Audiodeskrypcja pozwala osobom z niepełnosprawnością wzroku uczestniczyć w wydarzeniach teatralnych i podejmować dyskusje na temat sztuki na równi z osobami pełnosprawnymi. Dzięki dostępności sztuki audiowizualnej osoby niewidome i słabowidzące mogą brać udział w życiu społecznym i kulturalnym, nie zamykając się w środowisku niepełnosprawnych, co zapobiega ich wykluczeniu ze społeczeństwa. Teatr pełni tutaj funkcję terapeutyczną, motywuje osoby niepełnosprawne do wychodzenia z domu i przebywania z ludźmi. Sztuka uwrażliwia na piękno, wzbogaca widza w przeżycia, pobudza ciekawość i refleksję. Doskonałych rekomendacji i cennych informacji na temat udostępniania sztuk teatralnych poprzez wykorzystanie AD i udział w warsztatach teatralnych przybliżających treść i formę sztuki dostarczają wypowiedzi osób z niepełnosprawnością wzroku, które nie tylko chciałyby częściej brać udział w tego typu przedsięwzięciach, ale też poleciłyby je swoim znajomym. Wybrane opinie respondentów na temat udziału w warsztatach:

- „to fajna zabawa, która służy lepszemu zrozumieniu sztuki, wprowadza nas w jej klimat”;

- „dzięki takiemu przygotowaniu osoba niewidoma może samodzielnie oglądać sztukę";

- „spektakle z audiodeskrypcją polecam każdemu niewidomemu, ponieważ uważam, że to bardzo ułatwia oglądanie sztuki. Z kolei do udziału w warsztatach zachęcam zarówno osoby, które lubią występować przed ludźmi, dzielić się swoim talentem, pomysłowością, jak też tych nieśmiałych, by mogli się otworzyć";

- „poprzez aktywne działania na warsztatach mogę lepiej zrozumieć sztukę, którą później oglądam";

- „chętnie polecam warsztaty moim kolegom, ponieważ jest to ciekawa forma poznania teatru od kulis i szansa na lepsze zrozumienie wystawianego przedstawienia";

- „warsztaty dobrze byłoby polecić nawet osobom pełnosprawnym, by mogły lepiej poznać potrzeby osób niepełnosprawnych i zintegrować się z nimi” (Strachel 2015, s. 45).

Jak podkreśla Mariusz Trzeciakiewicz (b.d.), potrzeby osób z niepełnosprawnością stają się normalnym i powszechnie akceptowanym elementem rzeczywistości, w której każdemu człowiekowi powinny być zagwarantowane równe szanse w dostępie do wszelkich osiągnięć sztuki, urzędów i instytucji kultury. Dzięki tym działaniom osoby z niepełnosprawnością wzroku mogą zaspokoić swoje potrzeby, zwłaszcza wyższego rzędu. 


\section{Bibliografia}

Baraniewicz D., Gunia G. (2006). Zainteresowania kulturalne uczniów z upośledzeniem umysłowym. W: Baran J., Olszewski S. (red.). Świat pełen znaczeń - kultura i niepetnosprawność. Kraków: Oficyna Wydawnicza Impuls, s. 147-154.

Chmiel A., Mazur I. (2014). Audiodeskrypcja. Poznań: Uniwersytet im. Adama Mickiewicza.

Czykier K. (2013). Audiowizualne doświadczenie świata. Kontekst międzypokoleniowy. Warszawa: Wydawnictwo Akademickie Żak.

De Coster K., Loots G. (2004) Somewhere in between touch and vision: in search of a meaningful art education for blind individuals. „International Journal of Art and Design Education", 23 (3), s. 326-334.

Gajda J. (2012). Antropologia kulturowa. Wprowadzenie do wiedzy o kulturze. Część I. Kraków: Oficyna Wydawnicza Impuls.

Golka M. (2007). Socjologia kultury. Warszawa: Wydawnictwo Naukowe Scholar.

Grzebinoga A. (2011). Uczestnictwo osób niesłyszacych $w$ kulturze. W: Lubińska-Kościółek E., Plutecka K. (red.). Stymulowanie potencjału twórczego osób z różnymi potrzebami edukacyjnymi. Kraków: Oficyna Wydawnicza Impuls, s. 151-161.

Holland A. (2009). Audio description in the theatre and the visual arts: images into words. W: Cintas J.D. (red.). Audiovisual translation. Language transfer on screen. Basingstoke: Palgrave, s. 170-185.

Kuczyńska-Kwapisz J., Paplińska M. (2006). O twórczych kobietach radzących sobie $z$ dysfunkcja wzroku. W: Baran J., Olszewski S. (red.). Świat pełen znaczeń kultura i niepełnosprawność. Kraków: Oficyna Wydawnicza Impuls, s. 91-101.

Kukołowicz T. (2015). Gdzie i jaka kultura jest w Polsce dostępna? Dostępny na: http://www.nck.pl/obserwatorium-kultury/313863-gdzie-i-jaka-kultura-jest-w-polsce-dostepna-3/ (otwarty 25.11.2015).

Künstler I. (2014). Cel uświęca środki audiodeskrypcji. „Przekładaniec”, nr 28, S. $140-152$.

Künstler I., Butkiewicz U. Audiodeskrypcja, dostępny na: www.audiodeskrypcja. eu (otwarty 24.11.2015).

Makówka M. (2007). Funkcje uczestnictwa w kulturze. „Zeszyty Naukowe”, nr 742, s. 5-22.

Orero P. (2011). Audio description for children: once upon a time there was a different audio description for characters. W: Di Giovanni E. (red.). Entre texto y receptor: accesibilidad, doblaje y traducción. Frankfurt: Peter Lang, s. 169-184.

Paplińska M. (2008). Niepetnosprawność wzroku i jej psychospołeczna specyfika. W: Czerwińska M. (red.). Niewidomi w kulturze - od terapii do sztuki. Wybrane zagadnienia. „Przegląd Tyflologiczny”, nr 1-2 (38-39). Warszawa: PZN, s. 12-28.

Paplińska M. (2015) Sztuka coraz bardziej dostępna dla osób niewidomych i słabowidzacych. Audiodeskrypcja, dostępny na: http://www.trakt.org.pl/ 
sztuka-coraz-bardziej-dostepna-dla-osob-niewidomych-i-slabowidzacych-audiodeskrypcja/ (otwarty 30.11.2015).

Pichalski R. (1995). Czas wolny i rekreacja a rehabilitacja społeczna. „Szkoła Specjalna”, nr 4. Warszawa: WSPS, s. 210-218.

Pietruszyńska K. (2015). Audiodeskrypcja jako forma rehabilitacji osób z dysfunkcja wzroku. APS. Niepublikowana praca licencjacka.

Podgórska-Jachnik D. (2011). Refleksje o teatrze osób niepełnosprawnych w kontekście ich edukacji, samorealizacji i terapii. W: Lubińska-Kościółek E., Plutecka K. (red.) Stymulowanie potencjału twórczego osób z różnymi potrzebami edukacyjnymi. Kraków: Oficyna Wydawnicza Impuls, s. 93-120.

Strachel D. (2015). Udostępnianie sztuki dla osób z dysfunkcją wzroku lub słuchu $w$ Teatrze Rozmaitości w Warszawie. APS. Niepublikowana praca licencjacka.

Szarkowska A., Künstler I. Audiodeskrypcja w kinie, teatrze i muzeum. Wprowadzenie do działań praktycznych. W: Trzeciakiewicz M. (red.). Audiodeskrypcja w teorii i praktyce, czyli jak mówić o tym, czego nie można zobaczyć, s. 64-106, dostępny na: http://www.culturamentis.org/aktualnosci/pwp-do-przodu-podreczniki-do-pracy-z-os-niewidomymi/ (otwarty 30.11.2015).

Trzeciakiewicz M. (red.). Audiodeskrypcja $w$ teorii i praktyce, czyli jak mówić o tym, czego nie można zobaczyć, dostępny na: http://www.culturamentis.org/ aktualnosci/pwp-do-przodu-podreczniki-do-pracy-z-os-niewidomymi/ (otwarty 30.11.2015).

Wojnar I. (1970). Estetyka i wychowanie. Warszawa: PWN.

Żuraw H. (1995). Uczestnictwo kulturalne młodzieży niepełnosprawnej. Warszawa: Wydawnictwo Akademickie Żak.

\title{
THE BLIND AS A RECIPIENTS OF ART - SOCIAL, EDUCATIONAL AND REHABILITATIONAL MEANING OF AUDIO DESCRIPTION IN THE THEATRE FOR PEOPLE WITH VISUAL IMPAIREMENT
}

\begin{abstract}
Access to performing arts, including theatre performances is particularly important in social activation as well as education and rehabilitation of people with visual impairments. Theatre workshops can give blind individuals an opportunity to develop a sense of complete and active participation in artistic activities. Theatre performance audio description helps blind people understand visual concepts that are otherwise difficult to comprehend.
\end{abstract}

Key words: art accessible for the blind, audio description, understanding of concepts, theater workshops

Małgorzata Paplińska - doktor, adiunkt w Zakładzie Tyflopedagogiki Akademii Pedagogiki Specjalnej w Warszawie. Autorka książki Nauka brajla w weekend. Podręcznik dla studentów kierunków pedagogicznych, nauczycieli, wykładowców pracujacych z niewidomym uczniem i studentem (2009); redaktorka monografii Jak przygotować niewidome 
dziecko do nauki brajla. Przewodnik dla rodziców i nauczycieli (2012) oraz Edukacja równych szans. Uczeń i student z dysfunkcja wzroku - nowe podejście, nowe możliwości (2008); współredaktorka monografii Tyflopedagogika wobec współczesnej przestrzeni edukacyjno-rehabilitacyjnej (2015). Adres e-mail: m.paplinska@braille.pl. 